\title{
EFFECTS OF PROPRANOLOL ON GASTRIC SECRETION IN ALBINO RATS
}

\author{
P.K. DEBNATH, K.D. GODE, D. GOVINDA DAS \& A.K. SANYAL \\ Department of Pharmacology, Institute of Medical Sciences, Banaras Hindu University, Varanasi 221005, India
}

1 Effects of graded doses of propranolol have been studied on gastric secretion and gastric ulcers in pylorus-ligated rats.

2 A dose-dependent action of propranolol was observed; small doses increased total volume, acid output and pepsin secretion along with an increase in the incidence of ulcers but high doses were inhibitory.

\section{Introduction}

Reports of the effect of $\beta$-adrenoceptor antagonists on gastric secretion are contradictory. They have been reported either to stimulate secretion (Konturek \& Oleksy, 1969; Evan \& Lin, 1970), to inhibit secretion (Pradhan \& Wingate, 1966; Bass \& Patterson, 1967; Okabe, Saziki \& Takagi, 1970; Geumei, Issa, El-Gendi \& Abd-El-Samie, 1972; Geumei, Issa \& Abd-ElSamie, 1972; Danhof \& Geumei, 1972) or to have no effect on secretion (Haigh \& Stredman, 1968; Misher, Pendleton \& Staples, 1969). Similar controversy exists regarding the effect of $\beta$-adrenoceptor antagonists on the production of experimental gastric ulcers. Rosoff \& Goldman (1968), Djahanguiri, Sadeghi, Pousti, Hemmati \& Firouzabadi (1968), Djahanguiri, Sadeghi \& Hemmati (1968), Kohout, Korbova \& Svehlova (1970) and Pfeiffer \& Sethbhakdi (1971), have reported an increase in the incidence of ulcers but Takagi, Okabe, Yano, Kawashima \& Sazaki (1969), Okabe et al. (1970) and Danhof \& Geumei (1972), have found a significant decrease in the incidence of gastric ulcerations. It was, therefore, thought worthwhile to study the dose-response relationship of the effects of propranolol on both gastric secretion and gastric ulcer production in albino rats.

\section{Methods}

Inbred albino rats of either sex (approximately equal numbers in each group) and weighing $90-140 \mathrm{~g}$, were used. The gastric juice was collected after $4 \mathrm{~h}$ of pyloric ligation as described previously (Sanyal, Debnath, Bhattacharya \& Gode, 1971). The gastric contents were evacuated into a graduated tube by cutting along the greater curvature of the stomach, and centrifuged. The volume of the centrifuged sample was expressed as $\mathrm{ml} / 100 \mathrm{~g}$ body weight.

The free and total acid were determined by titrating with $0.01 \mathrm{~N} \mathrm{NaOH}$ using Töpfer's reagent and phenolphthalein as indicator, respectively, and are expressed as $\mathrm{mmol} / \mathrm{litre}$. The total acid output is expressed as $\mu \mathrm{mol} / 4$ hours.

Peptic activity was determined by a modification of the method of Anson (1938). One $\mathrm{ml} 1: 250$ (diluted with $0.01 \mathrm{M} \mathrm{HCl}$ ) gastric juice was added to $2.5 \mathrm{ml} 2 \%$ haemoglobin solution in $0.06 \mathrm{M} \mathrm{HCl}$. The mixture was incubated at $37^{\circ} \mathrm{C}$ for $20 \mathrm{~min}$ and immediately thereafter an equal volume $(3.5 \mathrm{ml})$ of ice cold $0.6 \mathrm{M}$ trichloracetic acid was added. The tubes containing the mixture were kept in an ice bath for another $15 \mathrm{~min}$ and then centrifuged to separate the precipitated proteins. One $\mathrm{ml}$ of the clear supernatant was used to determine the concentration of liberated amino acids by the method of Lowry, Rosebrough, Farr \& Randall (1951). The optical densities were determined with a Spectronic ' 20 ' absorptiometer set at $610 \mathrm{~m} \mu$ against a blank similarly prepared with $0.01 \mathrm{M} \mathrm{HCl}$ instead of diluted gastric juice. The peptic activity is expressed in terms of $\mu \mathrm{mol}$ tyrosine/ml gastric juice.

Gastric (Shay) ulcers were produced in the albino rats by pyloric ligation for 4 hours. The stomach was cut along the greater curvature and the mucosa was washed under a slow stream of water. The mucosa was examined with a magnifying glass for mucosal ulcers in the glandular region of the stomach. The ulcer index was determined as the sum of the length of each lesion in the stomach.

In all experiments, propranolol was administered intraperitoneally $30 \mathrm{~min}$ before pylorus ligation. All experiments were conducted at an ambient temperature of $28^{\circ} \pm 2^{\circ} \mathrm{C}$ during the 
months of August to October. Significance of the effects of different doses of propranolol on gastric secretion and pyloric-ligated ulcers was determined by Student's $t$ test.

\section{Results}

The graded doses of propranolol given intraperitoneally showed that a dose of $1 \mathrm{mg} / \mathrm{kg}$ caused a significant increase $(P<0.001)$ and $50 \mathrm{mg} / \mathrm{kg}$ caused a significant inhibition $(P<0.001)$ of the volume $(\mathrm{ml} / 100 \mathrm{~g})$, total acid output $(\mu \mathrm{mol} / 4 \mathrm{~h})$ and total peptic activity of the gastric juice. However, it was observed that although the total acid output decreased with propranolol, $50 \mathrm{mg} / \mathrm{kg}$, there was no significant change in the peptic activity/ml gastric juice (Table 1 ).

The effect of propranolol given intraperitoneally on pyloric-ligated ulcers was

Table 1 The effect of intraperitoneally administered graded doses of propranolol on volume, acid and pepsin content of gastric secretion in albino rats

\begin{tabular}{|c|c|c|c|c|c|c|c|c|}
\hline \multirow{2}{*}{$\begin{array}{c}\text { Propranolol } \\
\text { (mg/kg) }\end{array}$} & \multirow{2}{*}{$\begin{array}{c}\text { Body } \\
\text { weight } \\
\text { (g) }\end{array}$} & \multirow{2}{*}{$\begin{array}{c}\text { No. of } \\
\text { rats } \\
N(n)\end{array}$} & \multirow{2}{*}{$\begin{array}{l}\text { Volume } \\
(\mathrm{ml} / 100 \mathrm{~g})\end{array}$} & \multicolumn{2}{|c|}{ Acidity (mmol/l) } & \multirow{2}{*}{$\begin{array}{c}\text { Total acid } \\
\text { output } \\
\text { (umol/4 h) }\end{array}$} & \multicolumn{2}{|c|}{$\begin{array}{l}\text { Peptic activity } \\
\text { ( } \mu \mathrm{mol} \text { tyrosine) }\end{array}$} \\
\hline & & & & Free & Total & & $m I$ & output/4 h \\
\hline $\begin{array}{c}\text { Control } \\
(0.9 \% \text { saline })\end{array}$ & $\begin{array}{r}121.2 \\
\pm 5.8\end{array}$ & $38(1)$ & $\begin{array}{r}1.39 \\
\pm 0.16\end{array}$ & $\begin{array}{l}34.7 \\
\pm 4.1\end{array}$ & $\begin{array}{l}73.3 \\
\pm 3.7\end{array}$ & $\begin{array}{l}114.9 \\
\pm 14.2\end{array}$ & $\begin{array}{l}402 \\
\pm 89\end{array}$ & $\begin{array}{l}501 \\
\pm 55\end{array}$ \\
\hline 0.50 & $\begin{array}{r}124.3 \\
\pm 4.2\end{array}$ & $16(0)$ & $\begin{array}{r}1.31 \\
\pm 0.14\end{array}$ & $\begin{array}{l}28.5 \\
\pm 4.3\end{array}$ & $\begin{array}{l}70.9 \\
\pm 7.1\end{array}$ & $\begin{array}{l}104.2 \\
\pm 18.8\end{array}$ & $\begin{array}{l}321 \\
\pm 40\end{array}$ & $\begin{array}{l}472 \\
\pm 82\end{array}$ \\
\hline 0.75 & $\begin{array}{r}116.8 \\
\pm 6.1\end{array}$ & $15(0)$ & $\begin{array}{r}1.75 \\
\pm 0.28\end{array}$ & $\begin{array}{l}53.1^{*} \\
\pm 6.2\end{array}$ & $\begin{array}{l}81.2 \\
\pm 5.6\end{array}$ & $\begin{array}{l}165.1 \\
\pm 33.0\end{array}$ & $\begin{array}{l}480 \\
\pm 59\end{array}$ & $\begin{array}{l}859^{*} \\
\pm 156\end{array}$ \\
\hline 1.00 & $\begin{array}{r}122.6 \\
\pm 4.1\end{array}$ & $20(1)$ & $\begin{array}{l}3.23 t \\
\pm 0.29\end{array}$ & $\begin{array}{l}45.9 \\
\pm 4.0\end{array}$ & $\begin{array}{l}79.1 \\
\pm 3.0\end{array}$ & $\begin{array}{l}254.4 \dagger \\
\pm 24.6\end{array}$ & $\begin{array}{l}503 \\
\pm 48\end{array}$ & $\begin{array}{l}1634 \dagger \\
\pm 217\end{array}$ \\
\hline 2.00 & $\begin{array}{r}126.5 \\
\pm 5.4\end{array}$ & $16(0)$ & $\begin{array}{l}2.45 t \\
\pm 0.22\end{array}$ & $\begin{array}{l}54.8^{* *} \\
\pm 5.3\end{array}$ & $\begin{array}{l}76.5 \\
\pm 2.9\end{array}$ & $\begin{array}{l}189.2^{* *} \\
\pm 19.5\end{array}$ & $\begin{array}{l}463 \\
\pm 61\end{array}$ & $\begin{array}{l}1079 t \\
\pm 112\end{array}$ \\
\hline 4.00 & $\begin{array}{r}119.3 \\
\pm 3.1\end{array}$ & $15(0)$ & $\begin{array}{r}1.44 \\
\pm 0.24\end{array}$ & $\begin{array}{l}40.8 \\
\pm 5.9\end{array}$ & $\begin{array}{l}82.6 \\
\pm 4.9\end{array}$ & $\begin{array}{l}128.7 \\
\pm 31.1\end{array}$ & $\begin{array}{l}465 \\
\pm 34\end{array}$ & $\begin{array}{r}720 \\
\pm 144\end{array}$ \\
\hline 10.00 & $\begin{array}{r}121.4 \\
\pm 5.1\end{array}$ & $18(1)$ & $\begin{array}{r}1.11 \\
\pm 0.10\end{array}$ & $\begin{array}{l}66.7 t \\
\pm 6.3\end{array}$ & $\begin{array}{c}100.7 \dagger \\
\pm 4.4\end{array}$ & $\begin{array}{l}112.9 \\
\pm 12.4\end{array}$ & $\begin{array}{l}359 \\
\pm 28\end{array}$ & $\begin{array}{l}400 \\
\pm 72\end{array}$ \\
\hline 50.00 & $\begin{array}{r}120.9 \\
\pm 6.2\end{array}$ & $10(3)$ & $\begin{array}{c}0.48 \dagger \\
\pm 0.10\end{array}$ & $\begin{array}{l}44.9 \\
\pm 6.1\end{array}$ & $\begin{array}{l}98.3 t \\
\pm 2.7\end{array}$ & $\begin{array}{l}49.9 * * \\
\pm 13.3\end{array}$ & $\begin{array}{l}426 \\
\pm 42\end{array}$ & $\begin{array}{l}199 t \\
\pm 42\end{array}$ \\
\hline
\end{tabular}

The results are mean with s.e.

* * * + indicate statistical significance compared to control as $P<0.05,<0.01$ and $<0.001$ respectively.

$N(n)$ indicates number of rats taken per group and number of deaths in each group during the course of experiments after pyloric ligation.

Table 2 Effect of propranolol on pyloric-ligated ulcers

$\begin{array}{lccccc}\text { Treatment } & \begin{array}{c}\text { Dose } \\ \text { (mg/kg i.p.) }\end{array} & \begin{array}{c}\text { No. of } \\ \text { animals } \\ \text { N(n) }\end{array} & \begin{array}{c}\text { \% Incidence of } \\ \text { ulceration }\end{array} & \begin{array}{c}\text { Ulcer index } \\ \text { (mean with s.e.) }\end{array} & \text { P Value } \\ \begin{array}{c}\text { Control (0.9\% } \\ \text { saline) }\end{array} & - & 36(1) & 40 & 5.1 \pm 0.7 & \\ \begin{array}{l}\text { Propranolol } \\ \text { mantion }\end{array} & 0.5 & 28(1) & 37.3 & 4.5 \pm 0.7 & \\ & 0.75 & 15(0) & 86.6 & 11.3 \pm 1.5 & <0.001 \\ & 1.00 & 26(1) & 100.0 & 18.3 \pm 1.4 & <0.001 \\ & 2.00 & 17(0) & 100.0 & 16.6 \pm 1.3 & <0.001 \\ & 4.00 & 15(0) & 66.6 & 7.3 \pm 1.9 & \\ & 10.00 & 18(1) & 47.0 & 5.9 \pm 1.6 & <0.01\end{array}$

$N(n)$ indicates number of rats taken per group and number of deaths in each group during the course of experiments after pyloric ligation. 
dose-dependent; $1 \mathrm{mg} / \mathrm{kg}$ caused an increase while $50 \mathrm{mg} / \mathrm{kg}$ produced a significant decrease in the incidence of pyloric-ligated ulcers (Table 2).

\section{Discussion}

The present study indicates a dose-dependent response to propranolol on gastric secretion, especially the volume, in albino rats. The free and total acid $(\mathrm{mmol} / \mathrm{l})$ secretion significantly increased with an intraperitoneal dose of propranolol of $0.75 \mathrm{mg} / \mathrm{kg}$ and remained more or less constant with higher doses up to $50 \mathrm{mg} / \mathrm{kg}$. The acid output ( $\mu \mathrm{mol} / 4 \mathrm{~h}$ ) significantly increased with an intraperitoneal dose of $1 \mathrm{mg} / \mathrm{kg}$ but it decreased with gradual increase in dose because of the low volume of gastric secretion. These observations are in agreement with those of Takagi et al. (1970) who also reported an increase in free and total acid (mmol/l) secretion with a decrease in volume of secretion after intraperitoneal doses of $20 \mathrm{mg}$ and $50 \mathrm{mg} / \mathrm{kg}$ of propranolol. However, these workers also reported slight reduction in

\section{References}

ANSON, M.L. (1938). Estimation of pepsin, trypsin, papain and cathepsin with haemoglobin. J. Gen. Physiol., 22, 79-89.

BASS, P. \& PATTERSON, M.A. (1967). Gastric secretory responses to drugs affecting adrenergic mechanisms in rats. J. Pharmac. exp. Ther., 156, 142-149.

DANHOF, I.E. \& GEUMEI, A. (1972). Effect of propranolol on gastric acid secretion in rats. Br. J. Pharmac., 46, 170-171.

DJAHANGUIRI, B., SADEGHI, Dj. \& HEMMATI, S. (1968). Système orthosympathique et ulcères gastriques experimentaux. Arch. int. Pharmacodyn. Thér., 173, 154-161.

DJAHANGUIRI, B., SADEGHI, Dj., POUSTI, A., HEMMATI, S. \& FIROUZABADI, A. (1968). Effect of a single dose of phentolamine, MJ 1999 and isoproterenol on histamine induced gastric ulcer in guineapigs. Europ. J. Pharmac., 2, 315-316.

EVAN, D.C. \& LIN, T.M. (1970). Effect of propranolol on steady state pentagastrin induced $\mathrm{HCl}$ secretion and gastric mucosal blood flow in dogs. Physiologist, 13, 190.

GEUMEI, A., ISSA, I. \& ABD-EL-SAMIE, Y. (1972). Effect of $\beta$-adrenergic receptors stimulation and blockade on gastric acid secretion in pigeons. Pharmacology, 7, 29-35.

GEUMEI, A., ISSA, I., EL-GENDI, M. \& ABD-ELSAMIE, Y. (1972). Inhibitory effect $\beta$-adrenergic blocking agent propranolol on histamine stimulated gastric acid secretion in man. Amer. J. dig. Dis., 17, 55-58.

HAIGH, A.L. \& STREDM AN, W.M. (1968). The action of peptic activity. In the present series no such decrease could be observed. Furthermore, the present observations with propranolol $1 \mathrm{mg} / \mathrm{kg}$, intraperitoneally, differ from those reported by Danhof \& Geumei (1972) with propranolol $1 \mathrm{mg} / \mathrm{kg}$, given intravenously, in albino rats, where they observed a significant decrease in otal acid output.

The gastric ulcer index secondary to pylorus ligation followed closely the gastric secretory pattern. The incidence of ulceration was found to increase with intraperitoneal propranolol at a dose of $1 \mathrm{mg} / \mathrm{kg}$ and to decrease significantly with $50 \mathrm{mg} / \mathrm{kg}$. These observations do suggest that the ulcerogenic mechanism in pyloric-ligated rats is directly proportional to the total acid and pepsin output.

The mechanism by which smaller doses of propranolol increase and higher doses decrease gastric secretion cannot be ascertained with the present data.

Please send reprint requests to Dr A.K. Sanyal. catecholamines and adrenergic blockade on gastric blood flow and secretion in the dog. J. Physiol., Lond., 198, 79-80P.

KOHOUT, J., KORBOVA, L. \& SVEHLOVA, J. (1970). The effect of adrenoly tics on restraint ulcers. Advance abstracts, 4th World Congress of Gastroenterology, p. 305. Copenhagen.

KONTUREK, S.J. \& OLEKSY, J. (1969). The effect of cholinergic and adrenergic blockade on basal and pentagastrin induced acid secretion. Scand. J. Gastroent., 4, 13-16.

LOWRY, O.H., ROSEBROUGH, N.L., FARR, A.L. \& RANDALI, R.J. (1951). Protein measurement with Folin phenol reagent. J. biol. Chem., 193, 265-275.

MISHER, A., PENDLETÓN, R.G. \& STAPLES, R. (1969). Effects of adrenergic drugs upon gastric secretion in rats. Gastroenterology, 57, 294-299.

OKABE, S., SAZIKI, R. \& TAKAGI, K. (1970). Effect of adrenergic blocking agents on gastric secretion and stress induced gastric ulcer in rats. Jap. J. Pharmac., 20, 10-15.

PFEIFFER, C.J. \& SETHBHAKDI, S. (1971). Vascular impairment-an etiology factor in peptic ulcer. In: Peptic Ulcer, pp. 207-220., ed. Pfeiffer, C.J. Copenhagen: Munksgaard.

PRADHAN, S.N. \& WINGATE, H.W. (1966). Effect of some adrenergic blocking agents on gastric secretion in dogs. Arch. int. Pharmacodyn. Thér., 162, 303-310.

ROSOFF, C.B. \& GOLDMAN, H. (1968). Effect of the intestinal bacterial flora on acute gastric stress ulceration. Gastroenterology, 55, 193-196.

SANYAL, A.K., DEBNATH, P.K., BHATTACHARYA, 
S.K. \& GODE, K.D. (1971). The effect of cyproheptadine on gastric activity-an experimental study. In: Peptic Ulcer, pp. 312-318, ed. Pfeiffer, C.J. Copenhagen: Munksgaard.

TAKAGI, K., OKABE, S., YANO, S., KAWASHIMA, K. \& SAZA KI, R. (1969). The effect of propranolol on the stress and shay ulcerations in rats. Jap. J. Pharmac., 19, 327-329. 